\title{
Implementasi Nilai Pancasila Pada Siswa Kelas V di Sd Negeri Kebon Baru 4
}

\author{
Intan Indria Hapsari ${ }^{1}$, Sukarya ${ }^{2}$ \\ ${ }^{1,2}$ Sekolah Dasar 4 Kebon Baru, Indonesia
}

\begin{tabular}{l} 
Article Info \\
\hline Article history: \\
Received Jul 4, 2020 \\
Revised Ags 8, 2020 \\
Accepted Sep 28, 2020 \\
\hline
\end{tabular}

Keywords:

Nilai Pancasila

Sekolah Dasar

Siswa

\begin{abstract}
ABSTRAK
Tujuan Penelitian: Penelitian ini bertujuan untuk mendeskripsikan mengenai implementasi nilai-nilai Pancasila pada siswa kelas V di SD Negeri Kebon Baru 4, faktor pendukung dalam mengimplementasikan nilainilai Pancasila, dan faktor penghambat dalam mengimplementasikan nilainilai Pancasila di Sekolah Dasar Negeri 4 kebon baru.

Metode Penelitian: Jenis penelitian ini adalah penelitian kualitatif dengan pendekatan studi deskriptif. Partisipan dalam penelitian ini adalah Kepala Sekolah, Guru kelas V, dan tiga Siswa kelas V SD 4 Kebon baru. Pengumpulan data dilakukan melalui wawancara, observasi, dan dokumentasi. Data dianalisis dengan cara reduksi data, display data, dan penarikan simpulan. Teknik pemeriksaan keabsahan data menggunakan triangulasi teknik dengan sumber data dari hasil wawancara, observasi dan dokumentasi.

Temuan Utama: Penelitian yang dilakukan menunjukan bahwa siswa SD Negeri Kebon Baru 4 umumnya sudah mengimplementasikan nilai-nilai Pancasila yang diwujudkan dalam perilaku sehari-hari. Guru memasukkannya dalam materi ajar dan memanfaatkan lingkungan sekolah serta prasarana yang ada disekolah. Faktor pendukung dari implementasi nilai-nilai Pancasila ini yaitu adanya dukungan yang berasal dari Kepala Sekolah, Guru, dan masyarakat/wali murid serta sarana prasarana sekolah. Hambatan yang sering dihadapi guru yaitu pergaulan/pengaruh dari teman. Guru mengatasi hambatan tersebut dengan menegur dan melakukan bimbingan pada siswa.
\end{abstract}

Keterbaruan Penelitian: Keterbaruan penelitian ini dilihat dari instrument yang digunakan serta sampel yang digunakan.

This is an open access article under the $\mathrm{CC} B Y-N C$ license

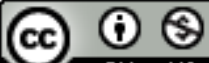

Corresponding Author:

Intan Indria Hapsari

Sekolah Dasar Negeri 4 Kebon Baru, Indonesia

Email: intanindirasari@gmail.com

\section{PENDAHULUAN}

Pendidikan merupakan salah satu faktor penting bagi kehidupan manusia. Pendidikan bertujuan untuk menumbuhkan budi pekerti pada anak, "Pendidikan umumnya berarti daya upaya untuk memajukan bertumbuhnya budi pekerti (kekuatan batin, karakter), pikiran (intelek), dan tubuh anak Pendidikan tidak boleh memisahkan bagian-bagian itu agar dapat memajukan kehidupan anak-anak agar selaras dengan dunianya, dan dapat membantu siswa dalam mencapai tujuan atau cita-cita [1]. Pendidikan yang baik akan berdampak terhadap Pendidikan yang baik akan berdampak terhadap manusianya dan juga terhadap kelangsungan hidupnya. Tingkat satuan pendidikan yang dianggap sebagai dasar dari pendidikan adalah sekolah dasar. Proses pendidikan di sekolah dasar sebagai sarana mempersiapkan peserta didik untuk 
memiliki pemahaman terhadap pola pikir peserta didik yang sesuai dengan Pancasila dan ciri khas serta watak ke-Indonesiaan. Pancasila dalam perjalanan bangsa Indonesia bukan sesuatu yang baru, melainkan sudah lama dikenal sebagai bagian dalam nilai-nilai budaya kehidupan bangsa Indonesia [2].

Nilai-nilai Pancasila tersebut dirumuskan sebagai dasar Negara Indonesia. Pancasila sebagai mana termuat dalam Pembukaan UUD 1945 tersebut dituangkan dalam wujud berbagai aturan-aturan dasar seperti yang termuat dalam Batang tubuh UUD 1945 dalam bentuk pasal-pasal, yang kemudian diajabarkan kembali melalui ketetapan MPR serta peraturan perundang-undangan lainnya, baik yang tertulis maupun tidak tertulis [3]. Pancasila sebagai dasar negara RI menjadi landasan warga negara Indonesia untuk mengembangkan nilai luhur dan moral yang berakar pada budaya dan keyakinan bangsa yang memungkinkan dapat diwujudkan dalam perilaku sehari-hari, baik sebagai individu, sebagai anggota masyarakat dan sebagai makhluk ciptaan Tuhan yang Maha Esa. Pendidikan kewarganegaraan (PKn) adalah mata pelajaran yang didalamnya terdapat nilai-nilai luhur yaitu nilai Pancasila. Pendidikan Kewarganegaraan (PKn) mengajarkan siswa tentang pengamalan terhadap Pancasila [4].

Permasalahan yang dihadapi akhir-akhir ini yaitu mulai kurangnya pengamalan dan pengetahuan mengenai Pancasila. Indikasi mulai berkurangnya pengetahuan dan pengamalan pancasila pada pelajar antara lain terjadinya erosi etika yang ditandai dengan lunturnya budaya sopan santun siswa pada guru, berkurangnya sikap cinta tanah air dan terjadinya dekadensi moral yang dimaknai menurunya sikap perilaku siswa [5]. Semakin lunturnya jiwa Pancasila dalam diri warga negara khususnya di kalangan pelajar sebagai penerus bangsa dapat mengancam keuutuhan dan keberlangsungan hidup bangsa Indonesia [6]. Cara yang dapat dilakukan untuk mengatasi permasalahan ini adalah dengan memberikan pengetahuan dan pemahaman mengenai nilai-nilai Pancasila sejak usia dini.. Dilain pihak, pada saat melakukan observasi di Sekolah Dasar Negeri (SDN) 1 Kedungrandu masih dijumpai beberapa siswa yang kurang memahami nilai-nilai Pancasila. Banyak siswa yang tidak begitu hafal isi sila Pancasila, selain itu mereka juga sering kali terbalik-balik urutanya dan masih ditemukan siswa yang suka bercanda saat melaksanakan upacara Bendera. Namun demikian, banyak juga siswa yang sudah paham mengenai Pancasila [7].

Hasil dari Uraian permasalahan di atas, peneliti berpendapat bahwa sekolah juga mempunyai peran yang sangat penting dalam mengeimplementasikan nilai-nilai Pancasila. Pendidikan dan penerapan nilai-nilai luhur bangsa yang terkandung dalam Pancasila sangat penting untuk dibiasakan pada anak. Mengingat pentingnya implementasi nilai-nilai Pancasila di Sekolah Dasar (SD) dan untuk mengetahui lebih lanjut menegnai pengamalan nilai-nilai Pancaisla, maka peneliti tertarik untuk melakukan penelitian dengan judul "Implementasi Nilai-Nilai Pancasila Pada Siswa Kelas V Di SD Negeri 1 Kedungrandu".

\section{METODE PENELITIAN}

Metode penelitian yang digunakan dalam penelitian ini adalah kualitatif deskriptif. Penelitian ini bertujuan untuk Penelitian ini bertujuan untuk mendeskripsikan mengenai implementasi nilai-nilai Pancasila pada siswa kelas V di SD Negeri Kebon Baru 4, faktor pendukung dalam mengimplementasikan nilai-nilai Pancasila, dan faktor penghambat dalam mengimplementasikan nilai-nilai Pancasila di Sekolah Dasar Negeri 4 kebon baru. Subjek dalam penelitian ini adalah Kepala Sekolah, Guru kelas V, dan tiga Siswa kelas V. Teknik pengumpulan data yang digunakan dalam penelitian ini yaitu, observasi, wawancara, dan dokumentasi. Teknik analisis data yang digunakan dalam penelitian ini adalah teknik analisis data kualitatif menurut Miles dan Huberman yaitu, reduksi data, penyajian data dan penarikan kesimpulan.

\section{HASIL DAN PEMBAHASAN}

Pentingnya memahami nilai-nilai Pancasila menjadi suatu kemutlakan agar dapat menjalankan kehidupan berkebangsaan dan bernegara yang baik. Pemahaman ini harus mulai ditanamkan sejak dini agar nilai-nilai Pancasila masuk menjadi roh dalam setiap perilaku bangsa Indonesia dan menjadi jati diri bangsa. Pemahaman (comprehension) adalah kemampuan seseorang untuk mengerti atau memahami sesuatu setelah sesuatu itu dketahui dan diingat, dengan kata lain pemahaman merupakan jenjang kemampuan berfikir yang setingkat lebih tinggi dari ingatan atau hafalan [8].

Upaya memberikan pemahaman mengenai nilai-nilai Pancasila di dalam pembelajaran agar dapat diterima siswa dengan baik tentunya harus dilakukan dengan strategi yang tepat. Strategi sekolah dalam memahamkan nilai-nilai sila Pancasila yaitu dengan membiasakan siswa dan dimasukkan dalam beberapa materi pelajaran dan disampaikan dengan mengembangkan metode pembelajaran [9]. Upaya aktualisasi Pancasila yang sesungguhnya akan sangat mendukung timbulnya berbagai perilaku yang sesuai dengan nilainilai yang terkandung di dalam Pancasila yang selanjutnya dapat diimplementasikan dalam kehidupan seharihari. 
Implementasi nilai-nilai Pancasila siswa kelas V di SDN 1 Keungrandu dicerminkan dari hubungan keseharian antara anggota sekolah, baik antara guru dengan guru, guru dengan siswa, maupun siswa dengan siswa lainnya. Kegiatan yang mencerminkan nilai-nilai Pancasila di SD Negeri Kebon Baru 4 yang sudah dilaksanakan diantaranya:

1. Implementasi Nilai-nilai Pancasila sila pertama (Ketuhanan Yang Maha Esa)

Nilai Ketuhanan Yang diantaranya pengakuan adanya kausa prima yaitu Tuhan Yang Maha Esa. Dalam sila Ketuhanan yang Maha Esa terkandung nilai bahwa Negara yang didirikan adalah sebagai perwujudan tujuan manusia sebagai makhluk Tuhan yang Maha Esa [10]. Pelaksanaan nilai Ketuhanan Yang Maha Esa yaitu: membiasakan budaya mengucapkan salam, berdoa sebelum dan sesudah pembelajaran, sholat dzuhur berjamaah, dan menghafal surat-surat pendek.

2. Implementasi nilai-nilai Pancasila sila kedua (kemanusiaan yang adil dan beradab)

Kemanusiaan yang Adil dan Beradab dalam Pancasila lebih bermakna kekeluargaan antar bangsa [11]. Nilai Kemanusiaan yang adil dan beradab emiliki makna menjunjung tinggi harkat dan martabat manusia sebagai makhluk Tuhan, menjunjung tinggi hak asasi manusia, menghargai kesamaan hak dan derajat tanpa membedakan suku, agama, ras keturunan, dan status sosial. Mengembangkan sikap saling mencintai sesama manusia, saling meghormati, serta menjunjung tinggi nilai-nilai kemanusiaan. Implementasi nilai-nilai sila ke-2 Pancasila di SDN 1 Kedungrandu diantaranya: budaya senyum, sapa dan salam, tidak memili-milih dalam berteman, dan tolong menolong.

3. Implementasi nilai-nilai Pancasila sila ke-3 (Persatuan Indonesia)

Persatuan Indonesia memiliki makna harus bersatu dan saling tolong-menolong. Sila ketiga Pancasila yaitu nilai persatuan bangsa yang mencakup seluruh wilayah Indonesia [12]. Menanamkan rasa cinta bangsa dan tanah air, guru memulainya dengan hal-hal yang ada di lingkungan diantaranya membudayakan kegiatan gotong royong dalam piket, kegiatan rutin Upacara Bendera setiap hari senin dan menjaga kebersihan lingkungan. Ruang kelas juga dipasang foto Presiden, Wakil Presiden, serta Burung Garuda sebagai wujud bangga terhadap bangsa Indonesia dan sikap cinta terhadap tanah air.

4. Implementasi nilai-nilai Pancasila sila ke-4 (Kerakyatan Yang Dipimpin Oleh Hikmah Kebijaksanaan dalam Permusyawaratan Perwakilan).

Implementasi nilai-nilai Pancasila sila ke-4 yang berbunyi "Kerakyatan Yang dipimpin Oleh Hikmat Kebijaksanaan Dalam Permusyawaratan Perwakilan” di SD Negeri Kebon Baru 4 yaitu yang pertama guru memberikan kesempatan yang sama pada siswa untuk menyampaikan pendapatanya kemudian siswa dapat menghargai pendapat orang lain serta menyelesaikan masalah dengan mengedepankan musyawarah mufakat. Guru dalam kegiatan pembelajaran selalu menerima masukan dari siswa dan berusaha bersikap bijaksana dalam menghadapi setiap permasalahan dalam kegiatan pembelajaran [13].

5. Implementasi nilai-nilai sila ke-5 (Keadilan Sosial Bagi Seluruh Rakyat Indonesia)

Sila kelima Pancasila yang berbunyi keadilan sosial bagi seluruh rakyat indonesia mengandung arti bahwa setiap warga negara berhak mendapatkan keadilan. Nilai-nilai Keadilan Sosial bagi Seluruh Rakyat Indonesia di dalamnya mengandung prinsip asasi (1) Keadilan; (2) Keadilan sosial; (3) Kesejahteraan lahir dan batin; (4) Kekeluargaan. Implementasi nilai-nilai Pancasila oleh siswa di SD Negeri Kebon Baru 4 diwujudkan dengan siswa tidak pilah pilih dalam berteman dan idak mencontek [14].

Pengimplementasian nilai-nilai Pancasila pada siswa kelas V di SD Negeri Kebon Baru 4 juga tidak terlepas dari faktor penghambat dan faktor pendukung. Faktor pendukung dalam mengimplemetasikan nilainilai sila Pancasila pada siswa kelas V di SD Negeri Kebon Baru 4 diantaranya dukungan diperoleh dari Kepala sekolah, guru, wali murid/masyarakat dan lingkungan sekolah. Faktor pengambat dalam mengimplemetasikan nilai-nilai Pancasila yaitu adanya pengaruh dari teman. Sekolah mengatasi hambatan tersebut dengan menegur dan melakukan bimbingan pada siswa.

\section{KESIMPULAN}

Nilai-nilai Pancasila secara umum telah diimplementasikan dalam kehidupan sehari- hari warga sekolah di SD Negeri Kebon Baru 4 , meskipun belum semua nilai dapat dapat terimplementasi dengan baik. Kegiatan yang dilakukan dalam mengimplementasikan nilai-nilai Pancasila di SD Negeri Kebon Baru 4 dilaksanakan oleh semua pihak sekolah, baik oleh guru, dan warga sekolah lainnya. Guru telah memasukan pembiasaan nilai-nilai Pancasila dalam materi ajar dengan memanfaatkan lingkungan sekolah dan kegiatan pembelajaran. Faktor pendukung implementasi nilai-nilai Pancasila oleh siswa kelas V di SD Negeri Kebon Baru 4 adalah dukungan dari Kepala Sekolah, Guru, dan masyarakat/wali murid serta sarana prasarana 
sekolah. Kepala Sekolah mendukung dengan mengadakan program sekolah yang dapat mengembangkan pengaamalan nilai-nilai Pancasila. Guru sebagai pelaksana menanamkan dalam diri siswa dalam berbagai kegiatan yang ada serta memanfaatkan lingkungan yang ada di sekolah untuk mengamalkan nilai-nilai Pancasila. Hambatan dalam pengimplementasian nilai-nilai Pancasila pada siswa kels V SD Negeri Kebon Baru 4 yaitu adanya pengaruh kurang baik dari teman. Upaya yang dilakukan guru untuk mengatasi hambatan tersebut yaitu dengan memberikan teguran dan melakukan bimbingan pada siswa yang belum mengimplementasikan nilai-nilai Pancasila

\section{UCAPAN TERIMA KASIH}

Terima kasih atas seluruh responden karena telah bersedia menjadi sampel dalam penelitian ini, serta seluruh stakeholder yang barkaitan saya ucapakan terima kasih.

\section{REFERENSI}

[1] Fuad, I. Dasar-dasar Kependidikan. Jakarta: PT Rineka Cipta. 2003

[2] S. Syahrial, A. Asrial, D. A. Kurniawan, P. Nugroho, R. Septiasari, R. A. Pratama, and R. Perdana, "Increased Behavior of Students' Attitudes to Cultural Values Using the Inquiry Learning Model Assisted Ethno constructivism," Journal of Educational Science and Technology (EST), vol. 5, no. 2, pp. 166-175, 2019

[3] Al Marsudi, S. Pancasila dan UUD’45 dalam Paradigma Reformasi. Jakarta: PT Raja Grafindo. 2006

[4] A. Asrial, S. Syahrial, D. A. Kurniawan, R. Septiasari, "Hubungan Kompetensi Pedagogik Dengan Kompetensi IPA Mahasiswa Pendidikan Guru Sekolah Dasar,” Pedagogia: Jurnal Penididikan, vol. 8, no. 2, pp. 149-157, 2019

[5] A. Astalini, D. Darmaji, W. Kurniawan, K. Anwar, and D. A. Kurniawan, "Effectivenes of Using E-Module and EAssessment," International Journal of Interactive Mobile Technologies (iJIM), vol. 13, no. 9, pp. 21-39, 2019

[6] D. A. Kurniawan, A. Astalini, D. Darmaji, and R. Melsayanti, "Students' attitude towards natural sciences," Int. J. Eval. \& Res. Educ, vol 8, no. 3, pp. 455-460, 2019

[7] D. Darmaji, D.A. Kurniawan and A. Lestari, "Deskripsi Keterampilan Proses Sains Mahasiswa Pendidikan Fisika Pada Praktikum Suhu dan Kalor,” JRKPF UAD, vol. 5, no. 2, pp. 68-72, 2018

[8] Sudijono, A. (2011). Pengantar Evaluasi Pendidikan. Jakarta: PT Raja Grafindo Persada.

[9] A. Asrial, S. Syahrial, D. A. Kurniawan, F. Chan, P. Nugroho, R. A. Pratama, and R. Septiasari, "Identification: The Effect Of Mathematical Competence On Pedagogic Competency Of Prospective Teacher," Humanities \& Social Sciences Reviews (HSSR), vol. 7, no. 4, pp. 85-92, 2019.

[10] Asmaroini, A. (2016). Implementasi Nilai-Nilai Pancasila Bagi Siswa Di Era Globalisasi. Citizenship: Jurnal Pancasila dan Kewarganegaraan. Vol. 4, No.2, Hal. 440-450.

[11] Kansil, C.S.T. (2011). Empat Pilar berbangsa dan Bernegara. Jakarta: PT Rineka Cipta.

[12] A. Asrial, S. Syahrial, D. A. Kurniawan, M. Subandiyo, and N. Amalina, "Exploring Obstacles in Leanguage Learning Among Prospective Primay School Teacher," International Journal of Evaluation and Research in Education, vol. 8, no. 2, pp. 249-254, 2019

[13] Sudaryanto. (2007). Kekeluargaan Sebagai Kunci Implementasi Pancasila. Jurnal Filsafat. Vol. 17, No. 2, Hal.151164

[14] D. A. Kurniawan, A. Astalini, D. Darmaji, R. Melsayanti, "Student's Attitude Towards Natural Science," International Journal of Evaluation and Research in Education (IJERE), vol. 8, no. 3, pp. 463-468, 2019 